\title{
1-O-trans-Cinnamoyl- $\beta$-D-glucopyranose: Alcohol Cinnamoyltransferase Activity in Fruits of Cape Gooseberry (Physalis peruviana L.)
}

\author{
Stefan Latza and Ralf G. Berger \\ Institut für Lebensmittelchemie, Universität Hannover, Wunstorfer Straße 14, \\ D-30453 Hannover, Germany \\ Z. Naturforsch. 52 c, $747-755$ (1997); received June 12/July 28, 1997 \\ Phenylpropanoid Metabolism, Glycoconjugate, Flavour Precursor, Aroma Ester, \\ Methyl Cinnamate \\ Methyl and ethyl cinnamate are aroma volatiles frequently occurring in fruits. Evidence \\ was obtained that the enzymatic transfer of cinnamic acid to endogenous alcohols present in \\ fruits (methanol, ethanol, 1-propanol) depended on energy-rich 1-O-glycosyl esters of cin- \\ namic acid which served as acyl donor molecules. A putative 1- $O$-trans-cinnamoyl- $\beta$-D-gluco- \\ pyranose: alcohol cinnamoyltransferase from cape gooseberry (Physalis peruviana L.) was \\ active towards 1- $O$-trans-cinnamoyl- $\beta$-D-glucopyranose and 1 - $O$-trans-cinnamoyl- $\beta$-D-gentio- \\ biose. The enzyme was purified 290 -fold by a protocol including ammonium sulphate precipi- \\ tation, solubilization by Triton X-100, gel permeation and affinity chromatography on conca- \\ navalin $\mathrm{A}$. The acidic glycoprotein $(p I=4.8)$ most probably is membrane bound. The \\ distribution of alcohol cinnamoyltransferase activity in gel chromatography fractions suggests \\ a native $M_{\mathrm{r}}$ of 75,000. For 1-O-trans-cinnamoyl- $\beta$-D-glucopyranose, an apparent $K_{\mathrm{m}}$ of $69 \mu \mathrm{M}$ \\ was determined. At $\mathrm{pH}>6.0$, non-enzymatic transesterification superposes the enzymatic \\ transformation.
}

\section{Introduction}

The flavour of many fruits is determined by volatile carboxylic acid esters. Methyl and ethyl cinnamate stand for widely occurring aroma esters (Maarse et al., 1994) possessing pleasant and balsamic, tropical-fruit-notes. Whereas in fruits methyl cinnamate generally is present at low concentrations, in some Eucalyptus species transmethyl cinnamate amounts to $94-99 \%$ of the oil yield, superseding Ocimum canum (basil, methyl cinnamate type), in which methyl cinnamate amounts to $87 \%$ of the total oil (Curtis et al., 1990). Apart from its flavour, methyl cinnamate is

\footnotetext{
Abbreviations: AAT, alcohol acyltransferase; ACT, alcohol cinnamoyltransferase; Con A, concanavalin A; FPLC, fast protein liquid chromatography; GC, gas chromatography; HCA, hydroxycinnamic acid; HPLC, high performance liquid chromatography; IEF, isoelectric focusing; PAA, polyacrylamide; PME, pectin methylesterase; PMSF, phenylmethylsulfonyl fluoride; PVDF, polyvinylidene difluoride; SDS-PAGE, sodium dodecyl sulfate-polyacrylamide gel electrophoresis; SPME, solid phase microextraction; TEMED, N,N, $N^{\prime}, N^{\prime}$-tetramethylethylene diamine.

Reprint requests to Prof. Dr. R. G. Berger. Telefax: (0049) 511-7624547.
}

assumed to possess several bioactivities. The cinnamic acid ester was held responsible for an ovipositional deterrence of the onion fly (Cowles et al., 1990), repellence to blackbirds (Avery and Decker, 1992), and larvicidal activity in Kaempferiae rhizoma (Kiuchi et al., 1988). Despite its frequent occurrence in the plant kingdom and its assumed range of bioactivity, the generation of methyl cinnamate in plant tissues remained unclear.

The objective of the present study was to reveal the enzymology associated with methyl and ethyl cinnamate formation in fruits. The biosynthesis of $O$-esters, such as the related hydroxycinnamic acid (HCA) conjugates in plants, in the majority of cases, proceeds via the HCA-coenzyme A thioesters or via the 1-O-HCA- $\beta$-glucosides (Mock and Strack, 1993). In the latter case, the formation of an $O$-ester by transfer of an HCA-moiety to an HO-bearing acceptor molecule is catalyzed by 1 - $O$-acylglucose-dependent $O$-acyltransferases (Strack and Mock, 1993).

In line with these results, 1-O-cinnamoylglycosides, as possible non-volatile progenitors, have been identified in several fruits (Latza et al., 1996a, b). In cape gooseberry (Physalis peruviana L.), 1$O$-trans-cinnamoyl- $\beta$-D-gentiobiose was detected. 
A previous study suggested a remarkable dependency of methyl cinnamate formation from treatment of cape gooseberries with methanol used as a general enzyme inhibitor (Berger et al., 1989). Therefore, fruits of $P$. peruviana were chosen for devising a purification protocol for a putative 1$O$-cinnamoylglycoside-dependent alcohol cinnamoyltransferase.

\section{Materials and Methods}

\section{Plant material}

Fruits of Colombian cape gooseberry (Physalis peruviana L.) were purchased from the local market. The surrounding dehydrated calycles were removed. Undamaged fruits, free from infection (visually inspected), were selected and stored at $10{ }^{\circ} \mathrm{C}$ until used for extraction.

\section{Chemicals}

1-O-trans-Cinnamoyl- $\beta$-D-glucopyranose and 1 $O$-trans-cinnamoyl- $\beta$-D-gentiobiose were synthesized as described (Latza et al., 1996a; Plusquellec et al., 1986). 1-O-trans-Cinnamoyl-6-O- $\alpha$-L-arabinofuranosyl- $\beta$-D-glucopyranose was isolated from fruits of Psidium guajava as reported previously (Latza et al., 1996a). The trans-cinnamoyl coenzyme A thioester was prepared by a mixed anhydride procedure (Fong and Schulz, 1981).

\section{Isolation and partial purification of alcohol cinnamoyltransferase}

All buffers contained $1 \mathrm{~mm}$ phenylmethylsulfonyl fluoride (PMSF, Sigma, Germany) as a protease inhibitor. Fruits of cape gooseberry (100 g) were homogenized with $120 \mathrm{ml}$ distilled water, $68 \mathrm{~g}$ dry ammonium sulfate and $20 \mathrm{mg}$ PMSF in a Rotor blender (Rotor AG, Switzerland) for $5 \mathrm{~min}$ at $14,000 \mathrm{rpm}$. The seeds were not broken up. After adjustment to $\mathrm{pH} 5.0$ with $2.0 \mathrm{~m} \mathrm{NaOH}$, the homogenate was centrifuged at $35,000 \times g$ for $20 \mathrm{~min}$. The pellet was resuspended in $40 \mathrm{ml}$ buffer A (50 mm sodium phosphate, $\mathrm{pH} 5.0$, containing $0.1 \%$ Triton $\mathrm{X}-100)$ and the suspension was centrifuged at $35,000 \times g$ for $20 \mathrm{~min}$. To the supernatant, which is termed the crude extract, dry ammonium sulfate $(14 \mathrm{~g})$ was added and dissolved by stirring. After centrifugation at $39,000 \times g$ for $20 \mathrm{~min}$, the precipitate was redissolved in $2.0 \mathrm{ml}$ buffer $\mathrm{A}$. In- soluble remainders were removed by centrifugation at $10,000 \times g$ for $10 \mathrm{~min}$. The enzyme extract was clarified by membrane filtration using a Chromafil $0.45 \mu \mathrm{m}$ polyvinylidene difluoride filter (PVDF, Macherey-Nagel, Germany).

For gel filtration chromatography, $0.5 \mathrm{ml}$ of enzyme extract was loaded onto a column of Superdex 200 HR 10/30 $(29.5 \times 1 \mathrm{~cm}$, Pharmacia, Sweden), which was pre-equilibrated with $50 \mathrm{~mm}$ sodium phosphate buffer, $\mathrm{pH}$ 5.0. Elution was carried out with the same buffer at a flow rate of $0.75 \mathrm{ml} / \mathrm{min}$ (Glass HPLC). Active fractions $(1.5 \mathrm{ml})$ were pooled, diluted with the threefold amount of buffer B (20 mm Tris-HCl, pH 7.4, $0.5 \mathrm{~m}$ $\mathrm{NaCl}, 1 \mathrm{~mm} \mathrm{MnCl}_{2}, 1 \mathrm{~mm} \mathrm{CaCl}_{2}$ ), and adjusted to $\mathrm{pH}$ 7.4. For affinity column chromatography, pooled samples of four repeated runs were applied onto a column of Con A Sepharose (FPLC, $4 \times 1$ $\mathrm{cm}$, Pharmacia), which had been equilibrated with buffer $\mathrm{B}$, at a flow rate of $1 \mathrm{ml} / \mathrm{min}$. The bound activity was eluted with a linear gradient of methyl $\alpha$-D-glucopyranoside $(0.0-0.2 \mathrm{M})$ in buffer B for $30 \mathrm{~min}$. Active fractions $(2 \mathrm{ml})$ were pooled and dialyzed against $10 \mathrm{~mm}$ sodium phosphate buffer, pH 5.0.

\section{Enzyme assays}

Enzyme activity of alcohol cinnamoyltransferase was determined by SPME/GC analysis of the methyl cinnamate formed (Yang and Peppard, 1994). The standard assay mixture contained $0.66 \mathrm{~m}$ methanol, $0.16 \mathrm{~mm} 1$ - $O$-trans-cinnamoyl- $\beta$ D-glucopyranose and $0.1 \mathrm{M}$ sodium phosphate buffer (buffer C), $\mathrm{pH}$ 5.0, in a final volume of $3.0 \mathrm{ml}$. The reaction was initiated by adding $1.0 \mathrm{ml}$ of enzyme solution ( $\mathrm{pH}$ 5.0). After incubation for $3 \mathrm{~h}$ at $40^{\circ} \mathrm{C}$, the reaction was terminated by instant freezing at $-20^{\circ} \mathrm{C}$. Prior to SPME liquid sampling, the rethawed mixture was diluted $1: 1$ with buffer C. Two $\mathrm{ml}$ of the solution were mixed with $0.8 \mathrm{~g}$ of dry $\mathrm{NaCl}$ and the SPME fiber, consisting of fused silica coated with $85 \mu \mathrm{m}$ polyacrylate (Supelco Inc., Bellefonte, PA), was inserted. Under stirring, the fiber remained in the liquid for $35 \mathrm{~min}$. For thermal desorption, it was subsequently introduced into the GC injector in splitless mode.

GC was carried out on a HRGC Fractovap 4160 chromatograph (Carlo Erba, Italy) equipped with 
a regular split/splitless inlet, a flame-ionization detector, a deactivated FS-Phenyl-Sil pre-column ( $3 \mathrm{~m} \times 0.32 \mathrm{~mm}$ i.d., CS, Germany), and a BC SE 54 fused silica column $(25 \mathrm{~m} \times 0.32 \mathrm{~mm}$ i.d., film thickness $0.4 \mu \mathrm{m}$, Leupold, Germany). Operating conditions were as follows: Carrier gas $\mathrm{H}_{2}$ at $3.25 \mathrm{ml} / \mathrm{min}$, injector $250^{\circ} \mathrm{C}$, detector $270{ }^{\circ} \mathrm{C}$. The column was held at $60^{\circ} \mathrm{C}$ for $5 \mathrm{~min}$ and temperature was increased to $250{ }^{\circ} \mathrm{C}$ at a rate of $3{ }^{\circ} \mathrm{C} /$ min. Dilutions of methyl cinnamate (Fluka, Germany) in $0.1 \mathrm{~m}$ buffer $\mathrm{C}$ were used to fit an external standard curve in the range of $0.1 \mu \mathrm{M}$ to $1.0 \mu \mathrm{M}$.

Pectin methylesterase (PME) activity in chromatographic fractions was monitored by a dyebased assay (Wojciechowsky and Fall, 1996), using highly esterified Pomosin pectin type B (Hercules/ Pomosin, Germany) as a substrate.

\section{Isoelectric focusing and gel activity detection of alcohol cinnamoyltransferase}

Isoelectric focusing was performed in polyacrylamide gels $(12 \times 12 \times 0.05 \mathrm{~cm}, 10 \%$ PAA $)$, polymerized from a mixture of $2.3 \mathrm{ml}$ double-distilled water, $7.6 \mathrm{ml}$ acrylamide/ bisacrylamide (32.5/1), $5.3 \mathrm{ml} \mathrm{60 \%} \mathrm{(v/v)} \mathrm{glycerol,} 0.8 \mathrm{ml}$ ampholytes $(\mathrm{pH}$ range from $3-10), 16 \mu \mathrm{l} 50 \%(\mathrm{w} / \mathrm{v})$ ammonium persulfate and $7 \mu \mathrm{l}$ TEMED. Prior to electrophoresis, active Con A fractions were dialysed against double-distilled water and concentrated by evaporation under reduced pressure at $30^{\circ} \mathrm{C}$. The cathode solution was $0.5 \mathrm{~m} \mathrm{NaOH}$ and the anode solution $0.5 \mathrm{~m}$ phosphoric acid. After prefocusing, gels were run at $200 \mathrm{~V}$ for $0.5 \mathrm{~h}$, then at $1000 \mathrm{~V}$ for additional $2.5 \mathrm{~h}$. Sample proteins and IEF standards ( $\mathrm{p} I$-range from 4.45-9.6, Bio-Rad, Germany) were stained with Coomassie blue. To positively detect alcohol cinnamoyltransferase activity, half of the gel was left unstained. Sections of the sample lane were cut out and incubated in the standard assay mixture as described above.

\section{Other analytical methods}

Standard procedures were used for measuring protein concentrations (Bio-Rad protein assay, based on Bradford, 1976) and for the determination of molecular weights (SDS-PAGE, 12\% PAA, Laemmli, 1970). Protein was visualized by staining with Coomassie brilliant blue. In addition, $M_{\mathrm{r}}$ of sample proteins was verified by rechromatography of active Con A fractions on Superdex 200 HR 10/ 30 , as described above (fractions of $0.75 \mathrm{ml}$ ).

\section{Studies on the substrate specificity of alcohol cinnamoyltransferase}

Substrate specificity was determined in the standard assay mixture, containing $0.16 \mathrm{~mm}$ of $1-O$ trans-cinnamoyl- $\beta$-D-gentiobiose, 1-O-trans-cinnamoyl-6- $O$ - $\alpha$-L-arabinofuranosyl- $\beta$-D-

glucopyranose, trans-cinnamoyl $\mathrm{CoA}$ and cinnamic acid, respectively, instead of the standard substrate. The alcohol substrate was varied by using $0.66 \mathrm{~m}$ ethanol and 1-propanol, respectively, instead of methanol.

\section{Determination of the $\mathrm{pH}$ - und temperature- optimum, kinetics}

Enzyme assays were carried out as described above, using $0.1 \mathrm{M}$ sodium phosphate buffer with $\mathrm{pH}$ between 2.0 and 12.0. Control experiments were carried out by using $1 \mathrm{ml}$ of the respective buffer instead of enzyme solution. The temperature-dependency of alcohol cinnamoyltransferase was analysed by incubation of the standard assay mixture at different temperatures between $10^{\circ} \mathrm{C}$ and $70{ }^{\circ} \mathrm{C}$. Determination of the apparent Michaelis-constant for 1-O-trans-cinnamoyl- $\beta$-D-glucopyranose (varied between $6.25 \mu \mathrm{m}$ and $1.25 \mathrm{~mm}$ ) was performed with fixed methanol concentration (0.66 м).

\section{Results}

\section{Enzyme preparation}

An enzyme mixture which showed alcohol cinnamoyltransferase activity was purified about 290fold from fruits of cape gooseberry (Physalis peruviana L.) by a procedure including ammonium sulphate precipitation, solubilization effected by Triton X-100, gel filtration and affinity chromatography. The overall recovery was $20 \%$ (Table I).

At about $60 \%$ ammonium sulphate saturation, the precipitable fraction of the initial homogenate was sedimented along with cell fragments and seeds. Out of the sediment, solubilization of alcohol cinnamoyltransferase activity could only be obtained after $0.1 \%$ Triton X-100 was included. This points to a membrane bound transferase. From the resulting crude extract, a precipitate was 
Table I. Purification of alcohol cinnamoyltransferase from cape gooseberry. Activity is expressed as nmol methyl cinnamate formed $/ \mathrm{min}$. The temperature was $40^{\circ} \mathrm{C}$. All other conditions are described under Materials and Methods.

\begin{tabular}{lcllrc}
\hline Purification step & $\begin{array}{l}\text { Total protein } \\
{[\mathrm{mg}]}\end{array}$ & $\begin{array}{l}\text { Total activity } \\
{[\mathrm{nmol} / \mathrm{min}]}\end{array}$ & $\begin{array}{l}\text { Specific activity } \\
{[\mathrm{nmol} / \mathrm{mg} \text { protein per } \mathrm{min}]}\end{array}$ & $\begin{array}{l}\text { Yield } \\
{[\%]}\end{array}$ & $\begin{array}{l}\text { Purification } \\
\text {-fold }\end{array}$ \\
\hline Homogenate & 187 & 5.70 & 0.030 & 100 & 1 \\
Crude extract & 31.4 & 4.46 & 0.142 & 78 & 4.7 \\
Redissolved precipitate & 19.0 & 4.32 & 0.227 & 76 & 7.6 \\
Superdex 200 HR 10/30 & 1.3 & 2.76 & 2.12 & 48 & 71 \\
Con A Sepharose & 0.13 & 1.13 & 8.69 & 20 & 290 \\
\hline
\end{tabular}

obtained after re-adjustment to $60 \%$ ammonium sulphate saturation. The precipitate was redissolved and used for subsequent gel permeation chromatography on Superdex 200 HR 10/30 (Fig. 1). Fractions corresponding to the major peak of alcohol cinnamoyltransferase activity (fractions 8 to 10, maximum activity in fraction 9) were subjected to affinity chromatography on a Con A Sepharose column (Fig. 2). After nonbound contaminants (flow-through) were washed out, the alcohol cinnamoyltransferase activity was eluted in a linear gradient of methyl $\alpha$-D-glucopyranoside, indicating that the enzyme is a glycoprotein. Although a single activity peak was eluted from the Con A column at a concentration of about $80 \mathrm{~mm}$ methyl $\alpha$-D-glucopyranoside (Fig. 2), subsequent reanalysis by gel permeation chroma-

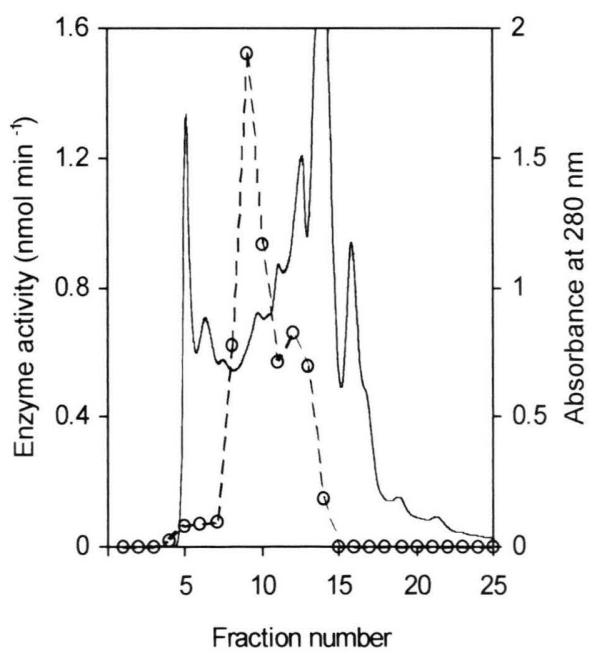

Fig. 1. Fractionation of the redissolved precipitate by gel permeation chromatography on Superdex 200 HR. Fractions $(1.5 \mathrm{ml})$ were assayed for alcohol cinnamoyltransferase activity $(\bigcirc)$. Maximum activity was detected in fraction 9 . Elution was monitored by recording absorbance at $280 \mathrm{~nm}(-)$. tography on Superdex 200 HR 10/30 revealed the presence of apparently three major proteins (Fig. 3). The distribution of alcohol cinnamoyltransferase activity in the chromatographic fractions suggested that the enzyme was the protein eluting first, thus having the highest molecular mass. Small activities of alcohol cinnamoyltransferase in the subsequent fractions were interpreted as a result of chromatographic tailing.

As pectin methylesterases (PME) from fruits frequently are described as glycoproteins (Glover and Brady, 1994), the presence of a PME in the final enzyme extract was expected. Indeed, the protein eluting last was found to exhibit pectin methylesterase activity (Fig. 3). In view of the low

Fraction number

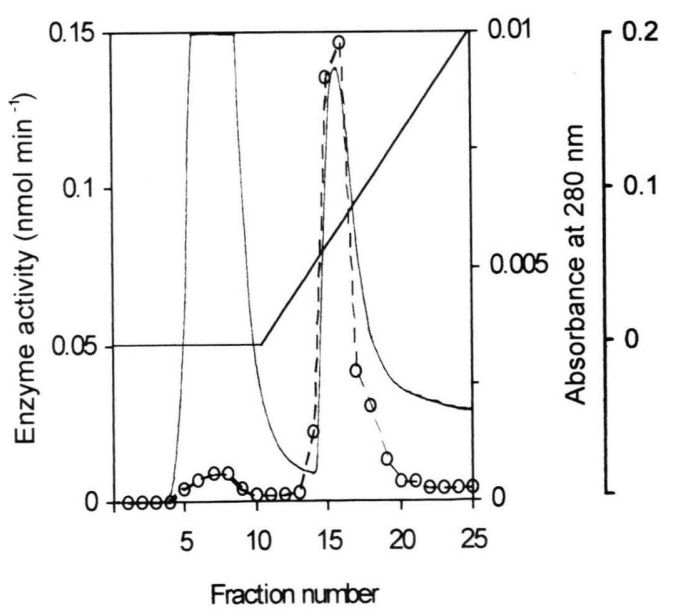

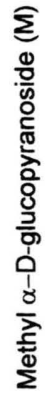

Fig. 2. Fractionation of active fractions from gel filtration by affinity chromatography on Concanavalin A. Fractions ( $2 \mathrm{ml})$ were assayed for alcohol cinnamoyltransferase activity $(\bigcirc)$. Gradient elution was started between fractions 10 and 11 . The active protein eluted at a concentration of about $80 \mathrm{~mm}$ methyl $\alpha$-D-glucopyranoside. Absorbance was recorded at $280 \mathrm{~nm}(-)$. 


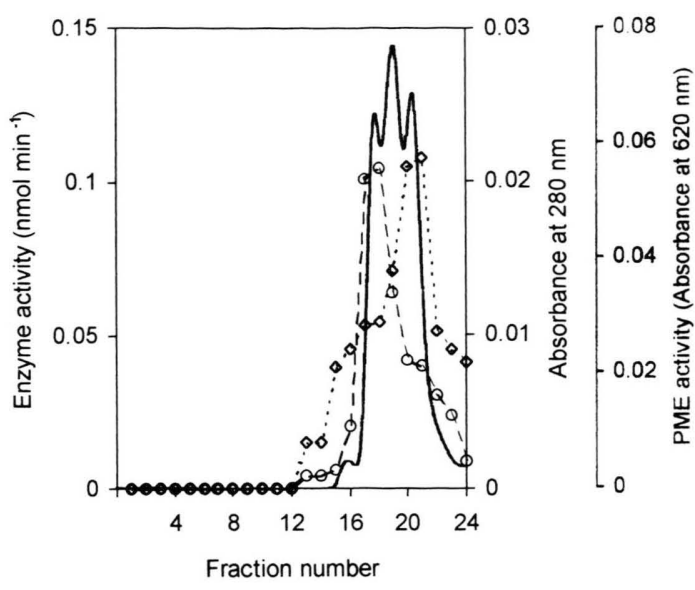

Fig. 3. Rechromatography of active fractions from Con A chromatography on Superdex 200 HR. Fractions $(0.75 \mathrm{ml})$ were collected and assayed for alcohol cinnamoyltransferase $(\bigcirc)$ and pectin methylesterase activities $(\diamond)$. Protein elution was monitored at $280 \mathrm{~nm}(-)$.

total protein content about $0.1 \mathrm{mg}$ absolute mass and minute specific activity, further attempts to fully separate the alcohol cinnamoyltransferase activity from the interfering polypeptides by FPLC or HPLC-based methods, or by preparative electrophoresis, failed. However, despite the incomplete purification, studies on kinetics and substrate specificity of alcohol cinnamoyltransferase resulted in coherent sets of data, as they were to be expected from a pure activity.

\section{Kinetic properties and substrate specificity}

Alcohol cinnamoyltransferase activity conformed to hyperbolic Michaelis-Menten kinetics. Under standard assay conditions, the apparent $K_{\mathrm{m}}$ value for 1- $O$-trans-cinnamoyl- $\beta$-D-glucopyranose, obtained from a single-reciprocal analysis (Fig. 4), was $69 \mu \mathrm{m}$. Substrate concentrations of 1-O-transcinnamoyl- $\beta$-D-glucopyranose were varied in the range of $6.25 \mu \mathrm{M}$ to $1.25 \mathrm{~mm}$, whereas the methanol content (second substrate) was kept constant at $0.66 \mathrm{M}$. Under these conditions no substrate inhibition could be observed, and apparent $V_{\max }$ was de-

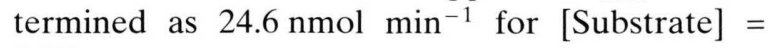
$1.25 \mathrm{~mm}$.

At a constant level of $0.16 \mathrm{~mm} 1$-O-trans-cinnamoyl- $\beta$-D-glucopyranose, concentrations of methanol were varied in the range of $49.3 \mathrm{~mm}$ to $7.40 \mathrm{M}$ $(0.2-30.0 \%, v / v)$. A linear relationship of product

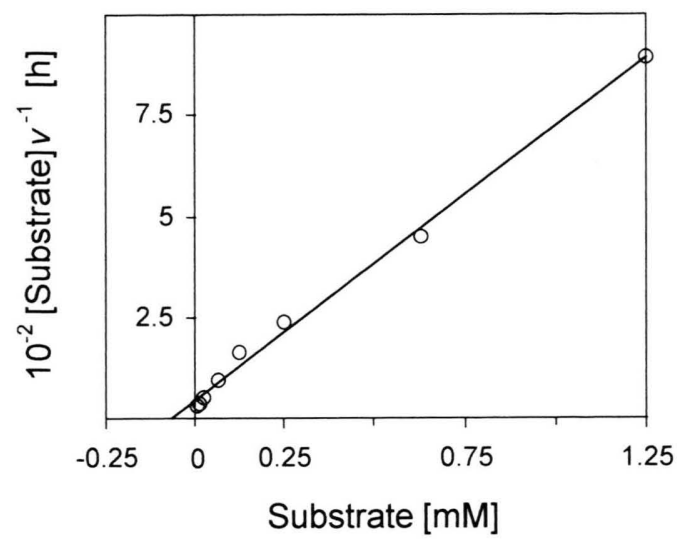

Fig. 4. Single-reciprocal Hanes kinetic plot of alcohol cinnamoyltransferase activity from cape gooseberry at a constant level of methanol $(0.66 \mathrm{~m})$. 1-O-trans-cinnamoyl- $\beta$-D-glucopyranose served as a substrate.

formation was observed up to $3.7 \mathrm{~m}$ of methanol $(15.0 \%, v / v)$, then rates of formation decreased (data not shown). At a methanol content of $7.40 \mathrm{M}$, still $67 \%$ of maximum activity could be observed.

The alcohols methanol, ethanol and 1-propanol all served as a substrate for alcohol cinnamoyltransferase. 1-O-trans-Cinnamoyl- $\beta$-D-gentiobiose, which is naturally occurring in cape gooseberry (Latza et al., 1996a), was accepted as acyl donor substrate, but the enzyme was inactive towards 1-O-trans-cinnamoyl-6- $O-\alpha$-L-arabinofuranosyl- $\beta$-D-glucopyranose from guava and towards trans-cinnamoyl CoA and free cinnamic acid.

\section{Temperature and $\mathrm{pH}$ dependency}

The temperature optimum was at $45^{\circ} \mathrm{C}$. As $\mathrm{pH}$ had a profound effect on product formation (Fig. 5), its value was kept constant at pH 5.0 during performance of activity assays. In the range between $\mathrm{pH} 4.0$ and 6.0 formation of methyl cinnamate solely was affected by alcohol cinnamoyltransferase activity. At higher $\mathrm{pH}$-values, that do not occur in a physiological environment, nonenzymatic transesterification readily can occur and overrides the enzymatic transformation. Above $\mathrm{pH} 10,1-O$-trans-cinnamoyl- $\beta$-D-glucopyranose is subjected to alkaline hydrolysis. As enzymatic and non-enzymatic transesterification competed in the range between $\mathrm{pH} 6.0$ and 10.0 , a $\mathrm{pH}$ optimum between $\mathrm{pH} 7.0$ and 8.0 was assessed by subtraction 


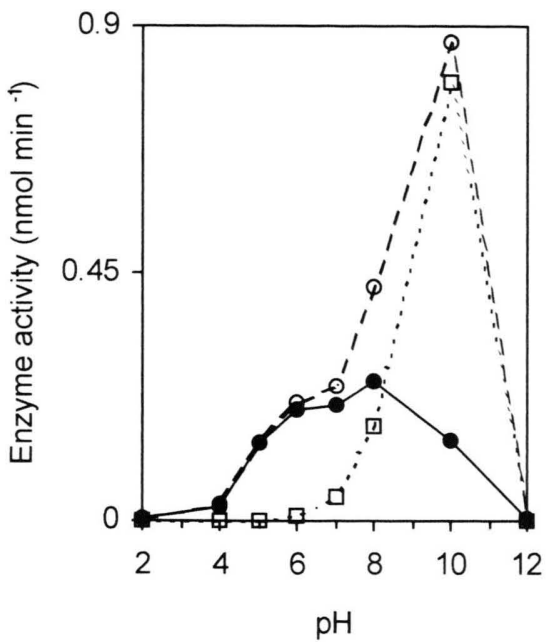

Fig. 5. Alcohol cinnamoyltransferase activity and incubation $\mathrm{pH}$-value. The enzymatic transformation $(-)$ results from subtraction of non-enzymatic transesterification (control, $\square$ ) from the combined reaction (total, $\bigcirc$ ).

of non-enzymatic rates (control) from the combined transformation (total).

\section{Isoelectric point and molecular mass}

The $\mathrm{p} I$-value of alcohol cinnamoyltransferase was determined by native IEF-PAGE based on the mobilities of IEF marker proteins. In accordance with the results of gel filtration chromatography, three bands of sample protein were detected at $\mathrm{p} I$ values of $8.4 ; 7.6$ and 4.8 . In order to locate the alcohol cinnamoyltransferase activity, half of the slab gel was left unstained, allowing the enzymes to maintain their activity. Respective sections were sliced and assayed for alcohol cinnamoyltransferase activity by incubation in the standard assay mixture. Activity was detected in the section covering $\mathrm{p} I=4.8$, indicating a rather acidic protein. No other protein band contained any transferase activity for the substrates used.

By gel permeation, native $M_{\mathrm{r}}$-values of 75,000 ; 48,500 and 31,000 were assigned to the three major bands (Fig. 3). In agreement with the IEF pattern, denaturing SDS-polyacrylamide gel electrophoresis also showed three major bands (Fig. 6). Considering the distribution of alcohol cinnamoyltransferase activity in gel chromatography fractions (Fig. 3), the transferase should exhibit the highest molecular weight of $75.0 \mathrm{kDa}$, corre-

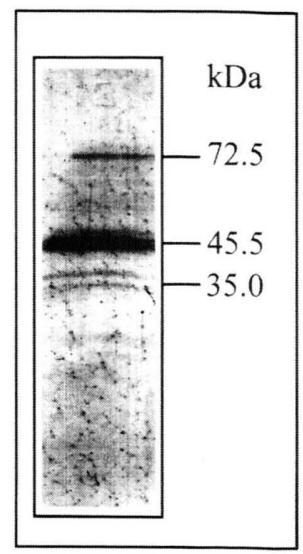

Fig. 6. SDS-polyacrylamide gel electrophoresis of the enzyme extract obtained by Con A chromatography. $0.13 \mathrm{mg}$ of sample protein was applied. $M_{\mathrm{r}}$ of protein bands was calculated from calibration with protein standards on a nearby lane of the gel. By comparison to the results of gel filtration, the upper band is expected to represent the alcohol cinnamoyltransferase, the lower, split band is supposed to reflect a pectin methylesterase.

sponding to $72.5 \mathrm{kDa}$ determined by SDS-PAGE. $M_{\mathrm{r}}$-values of 45,500 and 35,000 referred to the accompanying proteins. By analogy with the above considerations, the pectin methylesterase of cape gooseberry showed a native molecular weight of $31.0 \mathrm{kDa}$ (35.0 kDa by SDS-PAGE, respectively).

\section{Discussion}

The present study describes the enzymatic 1- $O$ acylglucose-dependent transfer of cinnamic acid to methanol, ethanol or 1-propanol by an activity isolated from cape gooseberry (Fig. 7). As acyl donor molecules, 1- $O$-cinnamoylglycosides recently have been identified in some fruits: 1-O-trans-Cinnamoyl- $\beta$-D-glucopyranose was isolated from strawberry, cowberry, guava (Latza et al., 1996 a,b) and blood orange (Mouly et al., 1997), 1-O-trans-cinnamoyl- $\beta$-D-gentiobiose was detected in cape gooseberry, and 1-O-trans-cinnamoyl-6- $O$ - $\alpha$-L-arabinofuranosyl- $\beta$-D-glucopyranose was obtained from fruits of guava (Latza et al., 1996a). For the closely related 1- $O$-sinapoyl- $\beta$-D-glucopyranose, it has been shown that $1-O$-acyl- $\beta$-glucosides have a high group-transfer potential, permitting subsequent transacylation reactions (Mock and Strack, 1993). 1-O-acylglycosides are regarded as possible pathway alternatives to CoA-dependent activation of 

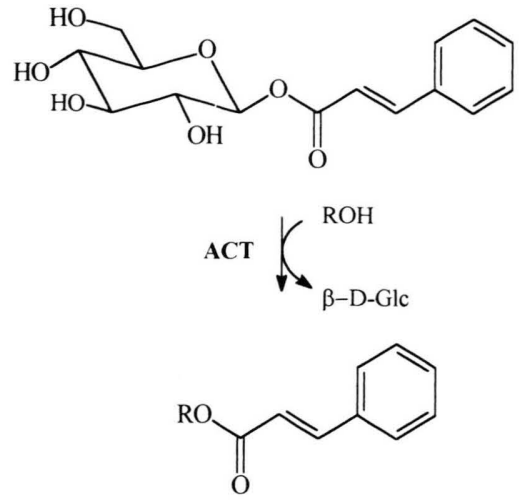

Fig. 7. Alcohol cinnamoyltransferase (ACT) catalyzed transfer of cinnamic acid from 1-O-trans-cinnamoyl- $\beta$-Dglucopyranose to methanol, ethanol or 1-propanol (ROH). The $\beta$-D-gentiobiose ester of cinnamic acid also serves as a substrate for ACT.

acyl-moieties, in particular regarding hydroxycinnamic acids (Strack and Mock, 1993). In accordance with this concept, there was no cofactor requirement of alcohol cinnamoyltransferase from cape gooseberry. As the acyl donor molecule, 1-Otrans-cinnamoyl- $\beta$-D-glucopyranose routinely was employed in the standard assay mixture. As a natural substrate occurring in cape gooseberry, 1-Otrans-cinnamoyl- $\beta$-D-gentiobiose was also accepted as an acyl donor, but with much less affinity. From kinetic studies (data not shown), apparent $K_{\mathrm{m}}$ was extrapolated to $3.5 \mathrm{M}$, compared to $69 \mu \mathrm{m}$ for 1-O-trans-Cinnamoyl- $\beta$-D-glucopyranose (Fig. 4). 1-O-trans-cinnamoyl-6- $O$ - $\alpha$-L-arabinofuranosyl- $\beta$-D-glucopyranose from guava did not serve as a substrate. Free cinnamic acid and transcinnamoyl CoA were not transformed to alkyl cinnamates. Additional studies will be necessary to show if $p$-coumaroyl-, caffeoyl-, feruloyl- or sinapoylglucose may serve as acyl-donor substrates. As our main interest referred to aroma biogenesis in fruits, no effort was made to synthesize and apply the ubiquitous 1 - $O$-glucose esters of hydroxycinnamic acids.

As the second substrate, methanol, ethanol and 1-propanol were employed as HO-acceptor molecules. These alcohols are the most abundant short chain alkanols of strawberry fruit. In the juice of ripe strawberries, $1.2 \mathrm{~mm}$ methanol, $0.2 \mathrm{~mm}$ ethanol and $0.1 \mathrm{~mm}$ 1-propanol, together amounting to $89 \%$ of the free alcohol content, were detected (Ueda et al., 1992).

Respective data on cape gooseberry were not available. The alcohols served directly in methyl, ethyl, and propyl cinnamate formation and were acylated with similar affinity. Since only methyl and ethyl cinnamate are of significance to the aroma of fruits, other alcohols were not tested.

As a result of the performed experiments, proof was given for 1-O-trans-cinnamoyl- $\beta$-D-glucopyranose: alcohol cinnamoyltransferase activity in enzyme extracts of cape gooseberry at $\mathrm{pH}<6.0$. An issue of particular importance is that the non-enzymatic transesterification reaction can readily result at $\mathrm{pH}>6.0$ (Fig. 5). To avoid the danger of obtaining artifactual results, assays for measuring alcohol cinnamoyltransferase activity were conducted at pH 5.0. The enzyme activity was monitored by analysis of formed alkyl cinnamates. As this demanded for a method of trace analysis, a recently developed and highly-sensitive variation of the adsorption techniques, solid phase microextraction (SPME, Yang and Peppard, 1994) was applied in combination with high-resolution gas chromatography.

The purification of alcohol cinnamoyltransferase ended up with a protein fraction containing three major proteins. After the last purification step, total protein mass was very low (Table I) and amounted to $0.13 \mathrm{mg}$. In view of the low specific activity, further attempts to complete the purification, failed. However, alcohol cinnamoyltransferase activity partially could be separated from an accompanying pectin methylesterase activity by gel filtration rechromatography (Fig. 3). Both, SDS-PAGE and IEF-PAGE of the final extract exhibited three major proteins. From IEF-PAGE, a major band at $\mathrm{p} I=4.8$ unequivocally was assigned to alcohol cinnamoyltransferase activity, whereas a native $M_{\mathrm{r}}$ of $75.0 \mathrm{kDa}$ was concluded from the distribution of transferase activity during gel filtration (Fig. 3).

In view of the low specific activity of 1-O-transcinnamoyl- $\beta$-D-glucopyranose: alcohol cinnamoyltransferase, the transferase reaction might reflect a side-activity of a known enzyme. The distinctive feature of the enzyme to yield a carboxylic acid methyl ester in the presence of methanol under aqueous conditions resembles the characteristics of non-specific lipid acyl hydrolases from dif- 
ferent plants and microorganisms (Mukherjee, 1994, 1990). Some of these lipolytic enzymes catalyze the transfer of acyl groups from a wide range of glycerolipids to methanol to yield methyl esters of fatty acids. So far, these enzymes seemingly are not dependent on activated acyl moieties. On the contrary, biosynthesis of aroma esters in fruits of strawberry, banana, melon, and apple repeatedly has been reported to be an acyl-CoA dependent reaction, catalyzed by acyl-CoA: alcohol acyltransferases (Fellmann et al., 1993, Pérez et al., 1996, Ueda et al., 1992, Wyllie et al., 1996). However, alcohol cinnamoyltransferase from cape gooseberry did not exhibit activity towards transcinnamoyl CoA. As alcohol cinnamoyltransferase activity also was detected in fruits of strawberry (data not shown), the enzyme seems to coexist with acyl-CoA-dependent alcohol acyltransferases. On account of its high content of pectins $(0,68 \%$, Lower, 1992) and polyphenols $\left(2,1 \mathrm{~g} \times \mathrm{kg}^{-1}\right.$, Perkins-Veazie, 1995), the above described method of

Avery M. L. and Decker D. G. (1992), Repellence of cinnamic acid esters to captive bed- winged blackbirds. J. Wildl. Manade 56, 800-805.

Berger R. G., Drawert F. and Kollmannsberger, H. (1989), The flavour of cape gooseberry (Physalis peruviana L.). Z. Lebensm. Unters. Forsch. 188, 122-126.

Bradford M. M. (1976), A rapid and sensitive method for the quantitation of microgramm quantities of protein utilizing the principle of protein-dye binding. Analyt. Biochem. 72, 248-253.

Cowles R. S., Miller J. R., Hollingworth R. M., AbdelAal M. T., Szurdoki F., Bauer K. and Matolcsy G. (1990), Cinnamyl derivatives and monoterpenoids as nonspecific ovipositional deterrents of the onion fly. J. Chem. Ecol. 16, 2401-2428.

Curtis A., Southwell I. A. and Stiff I. A. (1990), Eukalyptus, a new source of E-methyl cinnamate. J. Ess. Oil. Res. 2, 105-110.

Fellmann J. K., Mattinson D. S., Bostick B. C., Mattheis J. P. and Patterson M. E. (1993), Ester biosynthesis in Romé apples subjected to low-oxygen atmospheres. Postharvest Biol. Technol. 3, 201-214.

Fong J. C. and Schulz H. (1981), Short-chain and longchain enoyl-CoA hydratases from pig heart muscle. Methods Enzymol. 71, 390-398.

Glover H. and Brady C. (1994), Purification of three pectin esterases from ripe peach fruit. Phytochemistry 37, 949-955. enzyme purification turned out to be inapplicable to strawberry fruit. Therefore, strawberry alcohol cinnamoyltransferase was not further analyzed.

A glucose ester-dependent transferase reaction was first discovered in the biosynthesis of indolylacetic acid-myo-inositol ester in kernels of Zea mays (Michalczuk and Bandurski, 1980); meanwhile, there is increasing evidence that in particular the formation of hydroxycinnamic acid esters via 1- $O$-hydroxycinnamoyl glucosides plays an important role as an alternative to the CoA-dependent transferase reactions (Strack and Mock, 1993). In this report, evidence was provided for a related 1- $O$-cinnamoylglycoside-dependent transferase reaction which could be involved in aroma ester biogenesis.

\section{Acknowledgements}

The authors wish to thank Jan Taubert for assistance with gel electrophoresis and the Fonds der Chemischen Industrie for financial support.

Kiuchi F., Nakamura N., Tsuda Y., Kondo K., and Yoshimura H. (1988), Studies on crude drugs effective on visceral larva migrans. II. Larvicidal principles in Kaempferiae rhizoma. Chem. Pharm. Bull. 36, $412-$ 415.

Laemmli U. K. (1970), Cleavage of structural proteins during the assembly of head of bacteriophage T4. Nature 227, 680-685

Latza S., Ganßer D. and Berger R. G. (1996a), Carbohydrate esters of cinnamic acid from fruits of Physalis peruviana, Psidium guajava, and Vaccinium vitisidaea. Phytochemistry 43, 481-485.

Latza S., Ganßer D. and Berger R. G. (1996b), Identification and accumulation of 1-O-trans- cinnamoyl- $\beta$-Dglucopyranose in developing strawberry fruit (Fragaria ananassa Duch. cv. Kent). J. Agric. Food Chem. 44, $1367-1370$.

Lower E. S. (1992), Pectin and derived acids - manufacture properties uses. SÖWF-Journal 118, 655-657.

Maarse H., Visscher C. A., Willemsens L. C., Nijssen L. M. and Boelens M. H. (1994), Volatile Compounds in Food. Qualitative and Quantitative Data, Supplement 5 to the 6th Ed. and cumulative index. TNOCiVO, Zeist.

Michalczuk L. and Bandurski R. S. (1980), UDP-glucose: indoleacetic acid glucosyl transferase and indo leacetyl-glucose: myo-inositol indole-acetyl transferase. Biochem. Biophys. Res. Commun. 93, 588-592. 
Mock H.-P. and Strack D. (1993), Energetics of the uridine 5'-diphosphoglucose: hydroxycinnamic acid acylglucosyltransferase reaction. Phytochemistry 32, 575-579.

Mouly P. P., Gaydou E. M., Faure R. and Estienne J. M. (1997), Blood orange juice authentication using cinnamic acid derivatives. Variety differentiations associated with flavanone glycoside content. J. Agric. Food Chem. 45, 373-377.

Mukherjee K. D. (1994), Plant lipases and their application in lipid biotransformations. Prog. Lipid Res. 33, $165-174$.

Mukherjee K. D. (1990), Lipase-catalyzed reactions for modification of fats and other lipids. Biocatalysis $\mathbf{3}$, 277-293.

Pérez A. G., Sanz C., Olías R., Ríos J. J. and Olías J. M. (1996), Evolution of strawberry alcohol acyltransferase activity during fruit development and storage. J. Agric. Food Chem. 44, 3286-3290.

Perkins-Veazie P. (1995), Growth and ripening of strawberry fruit. Hort. Rev. 17, 267-297.

Plusquellec D., Roulleau F., Bertho F.,Lefeuvre M. and Brown E. (1986), Chimie des sucres sans groupements protecteurs -I- esterification regioselective de l'hydroxyle anomere du lactose, du maltose et du glucose. Tetrahedron 42, 2457-2467.
Strack D. and Mock H.-P. (1993), Hydroxycinnamic Acids and Lignins. In: Methods in Plant Biochemistry: Enzymes of Secondary Metabolism (Lea, P. J., Ed.) Academic Press, London, Vol. 9, pp. 45-97.

Ueda Y., Tsuda A., Bai J.-H., Fujishita N., Chachin K. (1992), Characteristic pattern of aroma ester formation from banana, melon, and strawberry with reference to the substrate specificity of ester synthetase and alcohol contents in pulp. Nippon Shokuhin Kogyo Gakkaishi 39, 183-187.

Wojciechowsky C. L. and Fall, R. (1996), A continuous fluorometric assay for pectin methylesterase. Analyt. Biochem. 237, 103-108.

Wyllie S. G., Leach D. N., Nonhebel H. N. and Lusunzi I. (1996), Biochemical pathways for the formation of esters in ripening fruit. In: Flavour Science: Recent Developments. (Taylor, A. J., Mottram, D. S., Eds.) The Royal Society of Chemistry, Cambridge, pp. 5257.

Yang X. and Peppard, T. (1994), Solid-phase microextraction for flavor analysis. J. Agric. Food Chem. 42, 1925-1930. 